\title{
Magnetic Anisotropy of Hard Milled Surfaces
}

Miroslav Neslušan ${ }^{1}$, Róbert. Farda ${ }^{1}$, Mária Čilliková ${ }^{1}$, Pavel Kejzlar ${ }^{2}$

${ }^{1}$ University of Žilina, Faculty of Mechanical Engineering, Univerzitná 1, 01026 Žilina, Slovak Republic; E-mail: miroslav.neslusan@fstroj.uniza.sk

${ }^{2}$ Institute for Nanomaterials, Technical University in Liberec, Studentská 1402/2, 46117 Liberec, Czech Republic

Grinding operations are sometimes replaced with hard turning or milling cycles. Mechanism of chip separation during grinding and the corresponding surface integrity remarkably differs from hard turning or milling. For this reason, this paper deals with application of Barkhausen noise for evaluation of surface anisotropy after hard milling. Experiments were carried out on bearing steel 100CrMn6 hardened on 45, 55, 62 HRC and one series without heat treatment. The analysis contains comparison of RMS values for the different hardness and tool wear after hard milling and also discusses the specific mechanism of BW motion in the case of cyclic magnetization.

Keywords: Barkhausen noise, hard milling, surface integrity

\section{Acknowledgement}

This article was edited under the financial support of KEGA project n. 005ŽU - 4/2014.

\section{References}

[1] KARPUCHEEWSKI, B. (2002). Introduction to micro magnetic techniques, ICBN 01, Hanover, 2002.

[2] MIČÚCH, M. et all. (2014). Micro magnetic study of cutting conditions and grinding wheel wear influence on surface integrity, Manufacturing Technology, Vol. 14, 2014, pp. 66-71.

[3] MOORTHY, V. et all. (2001). Evaluation of heat treatment and deformation induced changes in material properties in gear steels using magnetic Barkhausen noise analysis, ICBN 03, Tampere, 2001.

[4] OSIPAL, M. (2012). Application of Barkhausen noise for study of surface integrity of machined surfaces, PhD. Dissertation, University of Žilina, 2012.

[5] GUO, Y.B., SAHNI, J. (2004). A comparative study of hard turned and cylindrical ground white layers, Int. J. of Mach. Tool \& Manuf., vol. 44, 2004, pp. 135-145.

[6] BRANDT, D. (1995). Randzonenbeeinflussung beim Hartdrehen, PhD. Dissertation, Universität Hanover, 1995.

[7] NESLUŠAN, M. ROSIPAL, M. OCHODEK, V. (2011). Analysis of some aspects of surface integrity after grinding and hard turning trough Barkhausen noise, ICBN 09, Hejnice, 2011.

[8] NESLUŠAN, M. et.all (2012). Application of Barkhausen noise for analysis of surface integrity after hard turning, Manufacturing technology, Vol. 12, 2012, pp. 60-65.

[9] NESLUŠAN, M. et all (2014). Magnetic anisotropy in hard turned surfaces, Acta Physica Polonica, Vol.124, 2014 , pp. $188-189$. 